\title{
KECERDASAN NUMERIK DAN SPASIAL TERHADAP KEMAMPUAN MATEMATIS SISWA
}

\author{
Selviana Nabilah Aziz ${ }^{* 1}$, Indra Martha Rusmana ${ }^{2}$ \\ ${ }^{1}$ SMAN 6 Depok \\ ${ }^{2}$ Universitas Indraprasta PGRI Jakarta \\ selviana.aziz@gmail.com ${ }^{* 1}$, indramartharusmana@ymail.com²
}

\begin{abstract}
This study aims to determine: 1. The effect of numerical intelligence and spatial intelligence on students' mathematical abilities 2. The effect of numerical intelligence on students' mathematical abilities, 3. The effect of spatial intelligence on students' mathematical abilities. The research method used is a survey method with quantitative research on class X IPA Senior High School students of Depok City. The sampling technique was a simple random sampling of 120 samples. The data collection technique was given a test of 20 numerical intelligence items and 20 spatial intelligence items in the form of multiple-choice, while the mathematical ability data were taken from a 15 item test in the form of an essay. Before conducting the hypothesis test, the item validity test for the numerical intelligence test, the spatial intelligence test, and the mathematical ability test were carried out using simple regression correlation. The data normality calculations using the chi-square are declared normal-statistical hypothesis testing with $t$-test and $F$ test. The results of the study concluded that: 1. There is a significant influence between numerical intelligence and spatial intelligence on the mathematical abilities of students Senior High School students of Depok City, namely $f$ count $>f$ table $=21.81>3.07 ; 2$. There is a significant effect of numerical intelligence on the mathematical abilities of Depok City Senior High School students, namely $t$ count $>t$ table = $10.00>1.98 ; 3$. There is a significant effect of spatial intelligence on the mathematical abilities of Depok City Senior High School students, namely t count $>$ t table $=14.80>1.98$.
\end{abstract}

Keywords: Numerical Intelligence, Spatial Intelligence, Mathematical Ability

\begin{abstract}
Abstrak
Penelitian ini bertujuan untuk mengetahui: 1. Pengaruh kecerdasan numerik dan kecerdasan spasial terhadap kemampuan matematis siswa 2. Pengaruh kecerdasan numerik terhadap kemampuan matematis siswa, 3. Pengaruh kecerdasan spasial terhadap kemampuan matematis siswa. Metode penelitian yang digunakan adalah metode survey dengan penelitian kuantitatif pada siswa kelas $\mathrm{X}$ IPA SMA Negeri di Kota Depok. Teknik pengambilan sampel dengan simple random sampling terhadap 120 sampel. Teknik pengumpulan data berupa pemberian tes 20 butir soal kecerdasan numerik dan 20 butir soal kecerdasan spasial dalam bentuk pilihan ganda, sedangkan data kemampuan matematis diambil dari tes 15 butir soal dalam bentuk essay. Sebelum melakukan uji hipotesis dilakukan uji validitas butir soal untuk tes kecerdasan numerik, tes kecerdasan spasial, dan tes kemampuan matematis yang diuji menggunakkan korelasi regresi sederhana. Hasil perhitungan normalitas data menggunakan chi-kuadrat dinyatakan normal. Pengujian hipotesis statistik dengan uji t dan uji F. Hasil penelitian menyimpulkan bahwa: 1. Terdapat pengaruh yang signifikan antara kecerdasan numerik dan kecerdasan spasial terhadap kemampuan matematis siswa SMA Negeri Kota Depok yaitu diperoleh thitung $>$ tabel $=21,81>3,07 ; 2$. Terdapat pengaruh yang signifikan kecerdasan numerik terhadap kemampuan matematis siswa SMA Negeri Kota Depok yaitu diperoleh thitung $>$ ttabel $=10,00>1,98 ; 3$. Terdapat pengaruh yang signifikan kecerdasan spasial terhadap kemampuan matematis siswa SMA Negeri Kota Depok yaitu diperoleh thitung $>t_{\text {tabel }}=14,80>$ 1,98 .
\end{abstract}

Kata kunci: Kecerdasan Numerik, Kecerdasan Spasial, Kemampuan Matematis 
Jurnal Lebesgue : Jurnal Ilmiah Pendidikan Matematika, Matematika dan Statistika

Selviana Nabilah Aziz, Indra Martha Rusmana

Volume 2, No. 2, Agustus 2021 hal.233-244

DOI Artikel : 10.46306/lb.v2i2.32

\section{PENDAHULUAN}

Pada era globalisasi sekarang ini, pendidikan sangatlah berperan penting untuk meningkatkan kualitas sumber daya manusia. Perkembangan masyarakat pada era seperti sekarang ini makin mengalami percepatan serta meliputi seluruh aspek kehidupan dan penghidupan manusia. Percepatan perubahan ini terutama karena adanya perkembangan ilmu pengetahuan dan teknologi yang sangat berkembang pesat. Menurut Achdiyat, Maman. dkk. (2014) "Pendidikan adalah aktifitas yang dilakukan secara sengaja dan terencana oleh orang tua, guru, tokoh masyarakat, dan pendidik lainnya yang bertujuan untuk membantu peserta didikagar menjadi manusia yang mandiri fisik maupun mental”. Sedangkan menurut pendapat Angkowo dan Kosasih (2007) menyatakan bahwa "tujuan pendidikan yang humanistik adalah mengembangkan strategi dan teknologi yang lebih manusiawi dalam rangka menciptakan ketahanan dan keterampilan manusia guna menghadapi kehidupan yang secara terus menerus berubah".

Hal tersebut sejalan dengan fungsi dan tujuan pendidikan nasional yang tercantum pada Pasal 3 UU No.20 Tahun 2003 tentang sistem pendidikan nasional:

"Pendidikan nasional berfungsi mengembangkan kemampuan dan membentuk watak serta peradaban bangsa yang bermartabat dalam rangka mencerdaskan kehidupan bangsa, bertujuan untuk berkembangnya potensi siswa agar menjadi manusia yang beriman dan bertakwa kepada Tuhan Yang Maha Esa, berakhlak mulia, sehat, berilmu, cakap, kreatif, mandiri, dan menjadi warga negara yang demokratis serta bertanggung jawab".

Pendidikan merupakan tanggung jawab bersama, oleh karena itu perlu adanya pihak seperti orang tua, pihak sekolah, dan masyarakat umum untuk membantu peserta didik agar menjadi manusia yang berguna dan terampil dalam kehidupan mereka. Dengan pendidikan diharapkan siswa dapat mengembangkan potensi dirinya agar menjadi pribadi yang bermutu, serta memiliki keterampilan. Hakikat pendidikan adalah menyangkut ke semua lembaga pendidikan (pendidikan sekolah dan pendidikan luar sekolah) dalam rangka memposisikan seseorang tersebut sebagai manusia yang mampu menciptakan, berkarya, berbudi baik diri bagi kehidupan. Hal ini perlu disadari bahwa masalah yang dihadapi oleh dunia pendidikan pada saat ini adalah sangat beragam dan kompleks. Salah satu penyebabnya adalah semakin meningkatnya tuntutan bangsa dalam memenuhi kebutuhan serta keinginannya untuk maju. Oleh sebab itu pembelajaran di era seperti sekarang ini harus mampu memenuhi kebutuhan peserta didik, dengan cara mengembangkan keterampilan manusia dan teknologi yang dapat merencanakan tujuan hidup, membangun identitas diri, serta mengupayakan relasi dan komunikasi pribadi yang efektif dengan sesama manusia maupun dengan lingkungannya.

Menurut (Jayantika, 2013) Matematika sebagai salah satu mata pelajaran yang diajarkan di sekolah merupakan salah satu tolak ukur guna menciptakan SDM yang kompetitif. Matematika adalah salah satu cabang ilmu pengetahuan yang mempunyai peranan penting dalam perkembangan ilmu pengetahuan dan teknologi, baik sebagai alat bantu dalam penerapan-penerapan bidang ilmu lain maupun dalam pengembangan matematika itu sendiri. Sedangkan menurut (Rahmah, 2013) "Matematika terbentuk dari 
pengalaman manusia dalam dunianya secara empiris, kemudian pengalaman itu diproses di dalam dunia rasio, diolah secara analisis dengan penalaran sehingga terbentuk konsep- konsep matematika". Pendapat lain dari (Auliya, 2016) yaitu "dengan mempelajari matematika, seseorang terbiasa berpikir secara sistematis, ilmiah, menggunakan logika, kritis, dan dapat meningkatkan daya kreatifitasnya”.

Dengan memiliki kemampuan dalam matematika, seseorang dapat membentuk pola pikir sistematis, melakukan penalaran matematis, membuat dugaan, mengambil keputusan secara cermat, bersikap teliti, memiliki rasa ingin tahu yang tinggi, kreatif dan inovatif. Pentingnya belajar matematika tidak terlepas dari perannya dalam kehidupan, serta banyak masalah yang dapat disajikan ke dalam bentuk model matematika. Belajar matematika bertujuan melatih siswa agar berpikir sistematis, logis, kritis, dan kreatif dalam mengkomunikasikan ide atau memecahkan suatu masalah. Akan tetapi, matematika sebagai ilmu utama dalam pembelajaran masih memberikan kekuatan tersendiri bagi siswa. Pembelajaran matematika kini telah berpindah dari pandangan mekanistik kepada pemecahan masalah, meningkatkan pemahaman, dan kemampuan berpikir matematis.

Jika pada pengajaran matematika di masa lalu siswa diharapkan bekerja secara mandiri dan dapat menguasai materi matematika melalui latihan secara intensif. Selanjutnya, kurikulum yang digunakan saat ini, matematika didesain dan dikembangkan untuk mengembangkan daya matematis siswa, melalui inovasi dan implementasi berbagai pendekatan atau metode pembelajaran. Hal tersebut digunakan untuk membangun kecerdasan serta kreatifitas siswa atas kemampuan matematika mereka dalam kehidupan sehari-hari.

Dengan mempelajari matematika, seseorang dapat melakukan penalaran, berpikir secara sistematis, serta berpikir secara ilmiah, sehingga terbentuk konsep-konsep matematika dan dapat membentuk pola pikir matematis. Dalam berpikir matematis diperlukan dasar yaitu konsep yang melandasi suatu kemampuan proses berpikir matematis siswa. Indikator kemampuan berpikir matematis meliputi beberapa hal yaitu dapat menyelesaikan pemecahan masalah matematika, melakukan penalaran, kemampuan mengkomunikasikan matematika, kemampuan koneksi matematika, dan kemampuan representasi matematika. Kemampuan berpikir matematis merupakan hal yang penting, namun siswa yang menguasai konsep matematika tidak dengan sendirinya pintar dalam menyelesaikan masalah matematika, siswa harus melalui proses belajar pembelajaran matematika dengan sangat matang dan juga lebih sering menyelesaikan latihan-latihan soal matematika sehingga siswa memiliki kemampuan matematis yang baik.

Proses belajar pembelajaran yang berlangsung sesuai tujuan pembelajaran yang diinginkan didalam kelas tidak hanya siswa yang memiliki kemampuan berpikir matematis yang baik tetapi ditentukan oleh berbagai faktor seperti yang dijelaskan oleh Slameto (2010) belajar adalah suatu proses yang kompleks dengan banyak faktor yang mempengaruhinya. Faktor yang dimaksud adalah faktor eksternal dan faktor internal. Faktor eksternal merupakan faktor yang berasal dari luar diri siswa, seperti metode pembelajaran dan lingkungan. Sedangkan faktor internal adalah faktor yang berasal dari genetika atau dalam diri siswa, 
Jurnal Lebesgue : Jurnal Ilmiah Pendidikan Matematika, Matematika dan Statistika

Selviana Nabilah Aziz, Indra Martha Rusmana

Volume 2, No. 2, Agustus 2021 hal.233-244

DOI Artikel : 10.46306/lb.v2i2.32

yaitu seperti kecerdasan, emosi, dan sikap. Faktor internal memiliki peranan yang cukup besar dalam kemampuan berpikir matematis siswa, salah satunya yaitu kecerdasan.

Kecerdasan merupakan salah satu faktor yang dapat mempengaruhi kemampuan berpikir matematis siswa. Menurut Campbell yang dikutip oleh (Nurrahmah, 2015) kecerdasan adalah kemampuan untuk menyelesaikan masalah yang terjadi dalam kehidupan manusia, kemampuan untuk menghasilkan persoalan-persoalan baru untuk diselesaikan, dan kemampuan untuk menciptakan sesuatu. Sedangkan menurut (Gardner, 1999) :

"Kecerdasan terbagi menjadi 9 macam yaitu, Verbal-linguistic intelligence (Kecerdasan Linguistik), Logical-mathematical intelligence (Kecerdasan Logika Matematika dan Numerik), Spatialvisual intelligence (Kecerdasan Spasial), Bodily-kinesthetic intelligence (Kecerdasan Kinestetik), Musical intelligence (Kecerdasan Musik), Interpersonal intelligence (Kecerdasan Interpersonal), Intrapersonal intelligence (Kecerdasan intrapersonal), Naturalist intelligence (Kecerdasan tentang alam), and Existential intelligence (Kecerdasan Eksistensi)."

Tingkat kecerdasan yang dimiliki oleh setiap peserta didik pastilah berbeda-beda, ada yang memiliki tingkat kecerdasan tinggi, sedang, bahkan rendah. Kecerdasan akademik merupakan hal yang mutlak mempengaruhi keberhasilan seseorang pada dunia pendidikan, bahwa seseorang dapat dikatakan berhasil apabila seseorang tersebut memiliki kecerdasan akademik yang tinggi.

Menurut Irawan, Ari (2014) Ada beberapa faktor kecerdasan yang dimiliki siswa dan dapat mempengaruhi kemampuan berpikir matematis siswa yaitu salah satunya kecerdasan numerik. Kecerdasan numerik ini menyangkut hal tentang intelektual siswa yang merupakan suatu kemampuan potensial dalam melakukan operasi hitung seperti penjumlahan, pengurangan, perkalian, pembagian, dll. Sehingga kecerdasan numerik merupakan salah satu faktor yang dapat mempengaruhi kemampuan berpikir matematis siswa. Kecerdasan logis-matematika atau yang dikenal dengan kecerdasan numerik merupakan kemampuan dalam menghitung, mengukur, dan mempertimbangkan proposisi atau hipotesis, serta menyelesaikan operasi-operasi permasalahan matematika secara matematis. Selain kecerdasan numerik, faktor kecerdasan lain yang dapat mempengaruhi kemampuan berpikir matematis siswa yaitu kecerdasan spasial.

Menurut Pease, Barbara dan Allan (2009) kecerdasan spasial artinya mampu menggambarkan bentuk, dimensi, koordinat, proporsi, dan geografis objek dalam pikiran, termasuk mampu membayangkan jika suatu objek dirotasi, dipindah, dirubah arah dalam tiga dimensi. Kecerdasan spasial dapat didefinisikan sebagai kemampuan seseorang untuk memvisualisasikan gambar suatu objek atau pola. Sejalan dengan pendapat dari Albert (2005) mengatakan bahwa kecerdasan spasial yang berkaitan dengan matematika adalah aspek ruang, bangun, dan waktu. Seseorang yang memiliki kecerdasan spasial akan mempunyai kapasitas mengelola gambar, bentuk, dan ruang tiga dimensi. Sehingga, pembelajaran matematika dalam materi-materi tertentu sangat membutuhkan kemampuan spasial untuk menafsirkan bentuk-bentuk tiga dimensi, yaitu mencakup titik, garis, sudut, sisi, bidang ataupun ruang. 
Berdasarkan uraian latar belakang masalah, maka peneliti dapat mengambil kesimpulan dari uraian diatas bahwa mutu pendidikan tidak ditentukan oleh faktor tunggal, namun ada sejumlah variabel yang dianggap saling mempengaruhi. Hal itulah peneliti melakukan penelitian yaitu "Pengaruh Kecerdasan Numerik dan Spasial Terhadap Kemampuan Matematis Siswa”.

\section{METODE PENELITIAN}

Dalam penelitian ini metode yang digunakan adalah metode survey dengan Teknik pengambilan sampling Simple Random Sampling yaitu teknik pengambilan sampel yang memberikan peluang sama bagi setap anggota (unsur) populasi untuk dipilih menjadi anggota sampel. Adapun Desain penelitian adalah sebagai berikut:

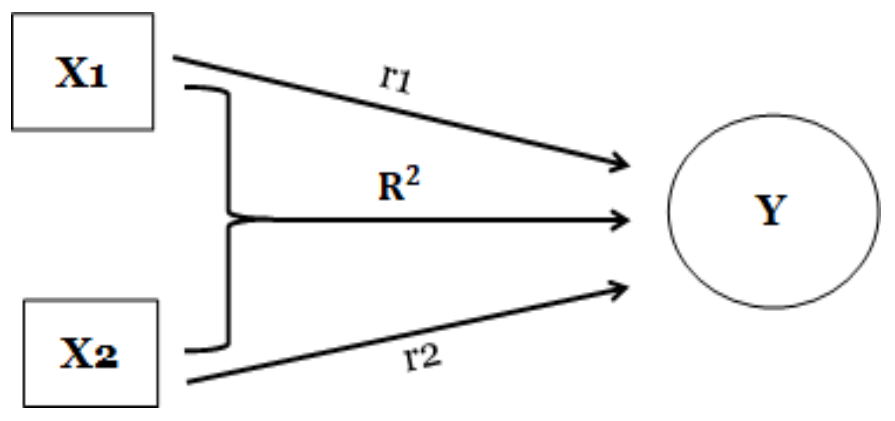

\section{Gambar 1. DESAIN PENELITIAN}

Keterangan :

$\mathrm{X}_{1}=$ Kecerdasan Numerik

$\mathrm{X}_{2}=$ Kecerdasan Spasial

$\mathrm{Y}=$ Kemampuan Matematis Siswa

$\mathrm{r}_{1} \quad$ = Hubungan Variabel $\mathrm{X}_{1}$ dengan $\mathrm{Y}$

$\mathrm{r}_{2} \quad$ = Hubungan Variabel $\mathrm{X}_{2}$ dengan $\mathrm{Y}$

$\mathrm{R}^{2}=$ Hubungan secara bersama-sama Variabel $\mathrm{X}_{1}$ dan $\mathrm{X}_{2}$ dengan $\mathrm{Y}$

Menurut Sugiyono (2017), Instrumen Penelitian adalah suatu alat yang digunakan mengukur fenomena alam maupun sosial yang diamati. Instrument harus relevan dengan masalah dan aspek yang akan diteliti agar memperoleh data yang akurat. Jadi, instrument penelitian hendaknya dapat menunjang data sesuai dengan yang dibutuhkan agar penarikan kesimpulan dapat secara akurat. Instrumen yang digunakan dalam penelitian ini adalah sebagai berikut:

\section{Soal Kecerdasan Numerik}

Kecerdasan numerik yaitu kemampuan berhitung, menalar angka-angka, menggunakan atau memanipulasi angka dan menguraikan secara logis, dalam menggunakan angka-angka dan penalaran (logika) meliputi di bidang matematika, berpikir secara konsep, dan dapat memecahkan persoalan matematika secara matematis. Kecerdasan numerik yang dimaksud dalam penelitian ini adalah skor dari 
hasil tes kemampuan numerik siswa. Aspek yang digunakan dalam tes pilihan ganda (PG). Adapun kisikisi instrumen kecerdasan numerik adalah sebagai berikut:

Tabel 1. Kisi-Kisi Tes Kecerdasan Numerik

\begin{tabular}{|c|c|c|c|}
\hline Variabel & Sub Variabel & Indikator & No. Soal \\
\hline \multirow[t]{2}{*}{$\begin{array}{c}\text { Kecerdasan } \\
\text { Numerik }\end{array}$} & $\begin{array}{l}\text { Kecerdasan untuk } \\
\text { relasi angka dan } \\
\text { konsep-konsep } \\
\text { menurut angka }\end{array}$ & $\begin{array}{l}\text { 1. } \begin{array}{l}\text { Memahami pengoperasian } \\
\text { (penjumlahan, pengurangan, }\end{array} \\
\text { perkalian dan pembagian) dan } \\
\text { sifat-sifat yang dimiliknya. } \\
\text { 2. Mampu melakukan } \\
\text { perhitungan sederhana } \\
\text { matematika. } \\
\text { 3. Memahami hubungan antara } \\
\text { angka dan kemampuan untuk } \\
\text { melakukan perhitungan } \\
\text { numerik. }\end{array}$ & $\begin{array}{l}1,2,4,5 \\
6,7,8,9 \\
10,17\end{array}$ \\
\hline & $\begin{array}{l}\text { Kemampuan dalam } \\
\text { materi Logaritma } \\
\text { dan Eksponen }\end{array}$ & $\begin{array}{l}\text { 1. Memahami pengoperasian } \\
\text { (penjumlahan, pengurangan, } \\
\text { perkalian dan pembagian) dan } \\
\text { sifat-sifat yang dimiliknya. }\end{array}$ & $\begin{array}{l}3,11 \\
12,13 \\
14,15 \\
16,18,19 \\
20\end{array}$ \\
\hline & Juml & Soal & 20 \\
\hline
\end{tabular}

\section{Soal Kecerdasan Spasial}

Kecerdasan spasial adalah kemampuan mengatasi atau mengelola gambar, bentuk, dan bangun ruang tiga dimensi, serta dapat memecahkan masalah matematika yang berhubungan dengan bangun ruang seperti geometri, vektor ataupun bangun ruang. Kecerdasan spasial yang dimaksud dalam penelitian ini adalah skor dari hasil tes kemampuan spasial siswa. Aspek yang digunakan dalam tes pilihan ganda (PG). Adapun kisi-kisi instrumen kecerdasan spasial adalah sebagai berikut:

Tabel 2. Kisi-Kisi Tes Kecerdasan Spasial

\begin{tabular}{|c|c|c|c|}
\hline Variabel & Sub Variabel & Indikator & $\begin{array}{l}\text { No. } \\
\text { Soal }\end{array}$ \\
\hline \multirow{4}{*}{$\begin{array}{c}\text { Kecerdasan } \\
\text { Spasial }\end{array}$} & $\begin{array}{l}\text { Kecerdasan } \\
\text { mengamati hubungan } \\
\text { posisi objek dalam } \\
\text { ruang } \\
\text { (spatial relation) }\end{array}$ & $\begin{array}{l}\text { 1. Memiliki persepsi tentang } \\
\text { arah dan pola suatu objek } \\
\text { ataupun simbol. } \\
\text { 2. Memahami gambar } \\
\text { berdasarkan bentuk dan } \\
\text { ukuran. }\end{array}$ & 1,2 \\
\hline & $\begin{array}{l}\text { Kemampuan untuk } \\
\text { memvisualisasikan } \\
\text { bentuk atau pola-pola } \\
\text { abstrak } \\
\text { (spatial orientation) }\end{array}$ & $\begin{array}{l}\text { 1. Mampu memvisualiasasikan } \\
\text { bentuk atau pola-pola } \\
\text { abstrak apabila dilihat dari } \\
\text { perspektif yang berbeda. }\end{array}$ & $\begin{array}{l}3,4 \\
8,9\end{array}$ \\
\hline & $\begin{array}{l}\text { Kemampuan untuk } \\
\text { mengidentifikasi } \\
\text { gambar } \\
\text { (spatial visualization) }\end{array}$ & $\begin{array}{l}\text { 1. Mampu mengidentifikasi } \\
\text { gambar yang berbeda dari } \\
\text { kelompok gambar tertentu } \\
\text { atau berdasarkan pasangan } \\
\text { gambar tertentu. }\end{array}$ & $\begin{array}{l}5,6, \\
7,10,11, \\
12\end{array}$ \\
\hline & $\begin{array}{l}\text { Kemampuan Materi } \\
\text { Vektor Bangun Ruang }\end{array}$ & $\begin{array}{l}\text { Kemampuan dalam } \\
\text { pemahaman materi vektor, } \\
\text { pengertian vektor, lambang } \\
\text { vektor, mencari panjang } \\
\text { vektor pada suatu garis dan } \\
\text { bangun ruang. }\end{array}$ & $\begin{array}{l}13,14, \\
15,16, \\
17,18,19, \\
20\end{array}$ \\
\hline
\end{tabular}




\section{Soal Kemampuan Matematis}

Kemampuan berpikir matematis dapat diartikan dengan daya matematis. Kemampuan berpikir matematis dapat dilakukan dengan cara bernalar atau berpikir secara logis, kritis, sistematis, kreatif, mampu memecahkan suatu masalah, beragumentasi dengan mengaitkan pembelajaran matematika ke dalam topiktopik bahasan matematika itu sendiri. Aspek yang digunakan dalam tes essay. Adapun kisi-kisi instrumen kemampuan matematis adalah sebagai berikut:

\section{Tabel 3. Kisi-Kisi Tes Kemampuan Matematis}

\begin{tabular}{|c|c|c|c|}
\hline Variabel & Sub Variabel & Indikator & No. Soal \\
\hline \multirow{5}{*}{$\begin{array}{l}\text { Kemampuan } \\
\text { Matematis }\end{array}$} & $\begin{array}{l}\text { Kemampuan } \\
\text { Pemecahan Masalah } \\
\text { Matematika } \\
\text { (Problem Solving) }\end{array}$ & $\begin{array}{l}\text { 1. Kemampuan memahami } \\
\text { masalah dan cara } \\
\text { menyelesaikan model } \\
\text { matematika. }\end{array}$ & $\begin{array}{c}7,8 \\
13,14\end{array}$ \\
\hline & $\begin{array}{l}\text { Kemampuan } \\
\text { Argumentasi/ } \\
\text { Penalaran } \\
\text { (Reasonning) }\end{array}$ & 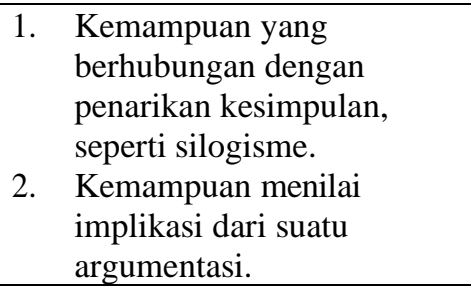 & 9,10 \\
\hline & $\begin{array}{l}\text { Kemampuan } \\
\text { Komunikasi } \\
\text { Matematika } \\
\text { (communication) }\end{array}$ & $\begin{array}{l}\text { 1. Kemampuan dalam } \\
\text { menggunakkan istilah- } \\
\text { istilah, notasi-notasi } \\
\text { matematika dan struktur- } \\
\text { strukturnya untuk } \\
\text { menyajikan ide, } \\
\text { menggambarkan hubungan- } \\
\text { hubungan dan model-model } \\
\text { situasi. } \\
\end{array}$ & $\begin{array}{c}1,2 \\
15\end{array}$ \\
\hline & $\begin{array}{l}\text { Kemampuan Koneksi } \\
\text { Matematika } \\
\text { (Connection) }\end{array}$ & $\begin{array}{ll}\text { 1. } & \text { Menerapkan konsep barisan } \\
\text { dan deret aritmatika. } \\
\text { 2. Memahami dan mencari } \\
\text { hubungan berbagai } \\
\text { representasi konsep } \\
\text { matematika. }\end{array}$ & $\begin{array}{c}3,4, \\
5\end{array}$ \\
\hline & $\begin{array}{l}\text { Kemampuan } \\
\text { Representasi } \\
\text { Matematika } \\
\text { (Representation) }\end{array}$ & 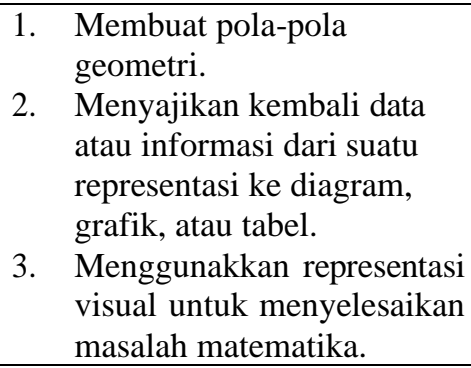 & $\begin{array}{c}6,11 \\
12\end{array}$ \\
\hline \multicolumn{3}{|c|}{ Jumlah Soal } & 15 \\
\hline
\end{tabular}




\section{HASIL DAN PEMBAHASAN}

\section{Hasil Penelitian}

Tabel 4. Tabel Penolong Perhitungan Koefisien Korelasi Variabel $X_{1}$ dan $X_{2}$ Terhadap $Y$

\begin{tabular}{|c|c|c|c|c|c|c|c|c|c|}
\hline & $\mathrm{X}_{1}$ & $\mathrm{X}_{2}$ & $\mathrm{Y}$ & $\mathrm{X}_{1}^{2}$ & $\mathrm{X}_{2}^{2}$ & $\mathrm{Y}^{2}$ & $\mathrm{X}_{1} \mathrm{Y}$ & $\mathrm{X}_{2} \mathrm{Y}$ & $\mathrm{X}_{1} \mathrm{X}_{2}$ \\
\hline$\Sigma$ & 8590,85 & 8750 & 8609 & 632725,30 & 652656,25 & 636561 & 629211,14 & 641593,75 & 633454,31 \\
\hline
\end{tabular}

Sumber: pengolahan data

\section{Koefisien Korelasi Ganda}

Hipotesis penelitian

$\mathrm{H}_{0}: r_{Y 12}=0$ (tidak terdapat hubungan antara kecerdasan numerik dan kecerdasan spasial bersama-sama dengan kemampuan matematis siswa)

$\mathrm{H}_{0}: r_{Y 12} \neq 0$ (terdapat hubungan antara kecerdasan numerik dan kecerdasan spasial bersama-sama dengan kemampuan matematis siswa)

Koefisien korelasi dihitung menggunakan rumus Korelasi Product Moment sebagai berikut:

$$
\begin{aligned}
& R=r_{Y 12}=\sqrt{\frac{r_{11}^{2}+r_{Y 2}^{2}-2 r_{Y 1} r_{Y 2} r_{12}}{1-r_{12}^{2}}} \\
& r_{Y 12}=\sqrt{\frac{(0,4668)^{2}+(0,4165)^{2}-2(0,4668)(0,4165)(0,4372)}{1-(0,4372)^{2}}} \\
& r_{Y 12}=\sqrt{\frac{0,3914-0,1700}{0,8089}} \\
& r_{Y 12}=0,52
\end{aligned}
$$

Karena nilai $\mathrm{r}_{\mathrm{Y} 12} \neq 0$ yaitu 0,52 maka tolak $\mathrm{H}_{0}$ yang diartikan terdapat hubungan antara kecerdasan numerik dan kecerdasan spasial secara bersama-sama terhadap kemampuan matematis siswa.

\section{Koefisien Determinasi Ganda $\mathrm{Y}$ atas $\mathrm{X}_{1}$ dan $\mathrm{X}_{2}$}

Dari nilai koefisien korelasi ganda $\mathrm{X}_{1}$ dan $\mathrm{X}_{2}$ terhadap $\mathrm{Y}$ sebesar 0,46 dapat dihitung koefisien determinasi dengan rumus :

$$
\begin{aligned}
& K D=R^{2}=\left(\begin{array}{ll}
r \quad 2 \times 100 \%
\end{array}\right) \\
& R^{2}=(0,52)^{2} \times 100 \% \\
& R^{2}=27,04 \%
\end{aligned}
$$

Artinya koefisien korelasi kecerdasan numerik dan kecerdasan spasial terhadap kemampuan matematis siswa sebesar $27,04 \%$ sedangkan $72,96 \%$ ditentukan oleh faktor (variabel) lain.

\section{Analisis Regresi Ganda}

Langkah-langkah persamaan regresi ganda dapat di bantu dengan tabel penolong deskripsi data sebagai berikut: 
Tabel 5. Tabel Penolong Perhitungan Analisis Regresi Ganda

\begin{tabular}{|c|c|c|c|c|c|c|c|c|c|}
\hline & $\mathrm{X}_{1}$ & $\mathrm{X}_{2}$ & $\mathrm{Y}$ & $\mathrm{X}_{1}^{2}$ & $\mathrm{X}_{2}^{2}$ & $\mathrm{Y}^{2}$ & $\mathrm{X}_{1} \mathrm{Y}$ & $\mathrm{X}_{2} \mathrm{Y}$ & $\mathrm{X}_{1} \mathrm{X}_{2}$ \\
\hline$\Sigma$ & 8590,85 & 8750 & 8609 & 17702,77 & 14635,42 & 18937 & 12889,24 & 13854,17 & 7038,16 \\
\hline
\end{tabular}

Sumber : pengolahan data

Persamaan umum regresi ganda dengan dua variabel bebas dan satu variabel tidak bebas sebagai berikut :

$$
\begin{aligned}
& \hat{Y}=a+b_{1} X_{1}+b_{2} X_{2} \\
& \hat{Y}=-13+0,43 X_{1}+0,74 X_{2}
\end{aligned}
$$

Artinya setiap penambahan 1 poin variabel $X_{1}$ akan memambahkan sebesar 0,43 poin variabel $Y$ dan setiap penambahan 1 poin variabel $\mathrm{X}_{2}$ akan menambahkan sebesar 0,74 poin variabel $\mathrm{Y}$.

$$
\begin{aligned}
& F_{\text {hitung }}=\frac{\mathrm{RJK}_{\mathrm{Reg}}}{\mathrm{RJK}_{\mathrm{Res}}}=\frac{\frac{\mathrm{JK}_{\text {reg }}}{\mathrm{k}}}{(\mathrm{J} 97,24} \\
& \mathrm{F}_{\text {hitung }}=\frac{}{26,86} \\
& \mathrm{~F}_{\text {hitung }}=29,4 \\
& \mathrm{~F}_{\text {tabel }} \text { ditentukan dari tabel distribusi F untuk } \alpha=0,05 \text { serta } \mathrm{dk}_{\text {pembilang }}=\mathrm{k}=2 \text { dan } \mathrm{dk}_{\text {penyebut }} \\
& =\mathrm{n}-\mathrm{k}-1=117
\end{aligned}
$$

Diperoleh $\mathrm{F}_{\text {tabel }(0,05 ; 2 ; 117)}=3,07$ Hipotesis yang diuji, yaitu :

$\mathrm{H}_{0}: \beta_{1}=\beta_{2}=0$ (regresi ganda $Y$ atas $X_{1}$ dan $X_{2}$ tidak signifikan) $H_{0}: \beta_{1}=\beta_{2} \neq 0$ (regresi ganda

$\mathrm{Y}$ atas $\mathrm{X}_{1}$ dan $\mathrm{X}_{2}$ signifikan)

Karena nilai $F_{\text {hitung }}>F_{\text {tabel }}(29,4>3,07)$ maka $\mathrm{H}_{0}$ ditolak, sehingga dapat disimpulkan terdapat pengaruh signifikan kecerdasan numerik dan kecerdasan spasial secara bersama- sama terhadap kemampuan matematis siswa.

\section{Uji Lanjut}

Menentukan thitung untuk masing-masing koefisien regresi

$t_{\text {hitung }}$ untuk koefisien regresi $\mathrm{b}_{1}$

$$
t_{b 1}=\frac{b_{1}}{s_{b 1}}=\frac{0,43}{0,043}=10,00
$$

$t_{\text {hitung }}$ untuk koefisien regresi $\mathrm{b}_{2}$

$$
\mathrm{t}_{\mathrm{b} 2}=\frac{\mathrm{b}_{2}}{\mathrm{~s}_{\mathrm{b} 2}}=\frac{0,74}{0,05}=14,80
$$

Dengan taraf signifikan $\alpha=0,05$ dan $\mathrm{dk}=\mathrm{n}-\mathrm{k}-1=117$ untuk uji dua pihak diperoleh $\mathrm{t}_{\text {tabel }}=1,98$.

Dari hasil diatas ternyata $t_{\text {hitung }}>t_{\text {tabel }}$ yaitu $10,00>1,98$ sehingga $\mathrm{H}_{0}$ ditolak.

Disimpulkan bahwa terdapat pengaruh yang signifikan kecerdasan numerik terhadap kemampuan matematis. Dari hasil diatas ternyata 14,80>1,98 maka $\mathrm{H}_{0}$ ditolak, sehingga dapat disimpulkan terdapat pengaruh yang signifikan kecerdasan spasial terhadap kemampuan matematis. 
Jurnal Lebesgue : Jurnal Ilmiah Pendidikan Matematika, Matematika dan Statistika

Selviana Nabilah Aziz, Indra Martha Rusmana

Volume 2, No. 2, Agustus 2021 hal.233-244

DOI Artikel : $10.46306 / \mathrm{lb} . v 2 \mathrm{i} 2.32$

\section{Pembahasan}

\section{Pengaruh Kecerdasan Numerik dan Kecerdasan Spasial Secara Bersama-sama}

\section{Terhadap Kemampuan Matematis Siswa}

Dari hasil penelitian, data kemampuan matematis (Y) terhadap 120 responden diperoleh nilai maksimum adalah 95 dan nilai minimum adalah 32 dengan rincian rentang data 63, banyak kelas 8, dan panjang kelas 8. Setelah dilakukan perhitungan distribusi frekuensi diperoleh nila i rata-rata (mean) 71,43; nilai tengah (median) 73,65; dan nilai yang paling sering muncul (modus) adalah 74,57. Simpangan baku dari data kemampuan matematis sebesar 12,74.

Dari hasil perhitungan data kecerdasan numerik $\left(\mathrm{X}_{1}\right)$ terhadap 120 responden diperoleh nilai maksimum adalah 93,37 dan nilai minimum adalah 40 dengan rincian rentang data 53, banyak kelas 8 , dan panjang kelas 7, setelah dilakukan perhitungan distribusi frekuensi diperoleh nilai rata-rata (mean) 69,66; nilai tengah (median) 70,10; dan nilai yang paling sering muncul (modus) adalah 70,30. Simpangan baku dari data kecerdasan numerik tersebut sebesar 11,67.

Dari hasil perhitungan data kecerdasan spasial $\left(\mathrm{X}_{2}\right)$ terhadap 120 responden diperoleh nilai maksimum adalah 93,75 dan nilai minimum adalah 50 dengan rincian rentang data 44, banyak kelas 8 , dan panjang kelas 6. Setelah dilakukan perhitungan distribusi frekuensi diperoleh nilai rata-rata (mean) 74,50; nilai tengah (median) 75,86; dan nilai yang paling sering muncul (modus) adalah 77,36. Simpangan baku dari data kecerdasan spasial tersebut sebesar 10,65.

Berdasarkan data dan analisis dari penelitian yang dilakukan diperoleh hasil korelasi ganda antara variabel kecerdasan numerik $\left(\mathrm{X}_{1}\right)$ dan kecerdasan spasial $\left(\mathrm{X}_{2}\right)$ secara bersama-sama terhadap kemampuan matematis $(\mathrm{Y})$ yaitu 0,52 , sehingga dapat diketahui bahwa kecerdasan numerik $\left(\mathrm{X}_{1}\right)$ dan kecerdasan spasial $\left(\mathrm{X}_{2}\right)$ memberikan pengaruh terhadap kemampuan matematis $(\mathrm{Y})$ sebesar 27,04\%. Artinya ada sebesar 27,04\% kemampuan matematis dapat dipengaruhi oleh variabel kecerdasan numerik dan kecerdasan spasial secara bersama-sama, sisanya $72,96 \%$ dipengaruhi oleh faktor lain.

Persamaan regresi ganda pada penelitian ini adalah $\hat{Y}=-13+0,43 X_{1}+0,74 X_{2}$. Artinya bahwa kecerdasan numerik dan kecerdasan spasial pada siswa secara bersama- sama akan memberikan kenaikan yaitu sebesar 0,43 untuk variabel $\mathrm{X}_{1}$ dan 0,74 untuk variabel $\mathrm{X}_{2}$ terhadap variabel $\mathrm{Y}$. Setelah dilakukan uji signifikan regresi ganda memakai uji $\mathrm{F}$ dengan membandingkan antara nilai $\mathrm{F}_{\text {hitung }}$ dengan nilai $\mathrm{F}_{\text {tabel }}$, diperoleh nilai $F_{\text {hitung }}$ adalah 29,4 sedangkan nilai $F_{\text {tabel }}$ adalah 3,07. Nilai $F_{\text {hitung }}(29,4)>F_{\text {tabel }}(3,07)$,sehingga dinyatakan $\mathrm{H}_{0}$ ditolak. Disimpulkan bahwa terdapat pengaruh yang signifikan antara kecerdasan numerik $\left(\mathrm{X}_{1}\right)$ dan kecerdasan spasial $\left(\mathrm{X}_{2}\right)$ secara bersama-sama terhadap kemampuan matematis $(\mathrm{Y})$. 
Jurnal Lebesgue : Jurnal Ilmiah Pendidikan Matematika, Matematika dan Statistika

Selviana Nabilah Aziz, Indra Martha Rusmana

Volume 2, No. 2, Agustus 2021 hal.233-244

DOI Artikel : $10.46306 / \mathrm{lb} . v 2 \mathrm{i} 2.32$

\section{Pengaruh Kecerdasan Numerik Terhadap Kemampuan Matematis}

Berdasarkan data dan analisis yang dilakukan diperoleh hasil korelasi antara variabel kecerdasan numerik $\left(\mathrm{X}_{1}\right)$ terhadap kemampuan matematis $(\mathrm{Y})$ yaitu sebesar 0,47 ; sehingga kecerdasan numerik memberikan pengaruh yang cukup signifikan terhadap kemampuan matematis sebesar $21,79 \%$. Artinya kontribusi variabel $\mathrm{X}_{1}$ terhadap $\mathrm{Y}$ sebesar 21,79\% sedangkan sisanya 78,21\% dipengaruhi oleh faktor lain.

Persamaan regresi pada penelitian ini adalah $\hat{Y}=19,48+0,73 X$, Berarti bahwa setiap peningkatan 1 data kecerdasan visual-spasial akan memberikan kenaikan sebesar 0,73 terhadap kemampuan matematis siswa. Setelah melakukan uji linieritas kecerdasan numerik $\left(\mathrm{X}_{1}\right)$ terhadap kemampuan matematis $(\mathrm{Y})$ didapat $\mathrm{F}_{\text {hitung }}<\mathrm{F}_{\text {tabel }}$ yaitu 0,94 $<2,09$ berarti data berpola linier, sehingga analisis regresi dapat dilanjutkan.

Kemudian dilakukan uji lanjut koefisien regresi sederhana memakai uji t dengan membandingkan antara nilai $t_{\text {hitung }}$ dengan nilai $t_{\text {tabel }}$, diperoleh nilai $t_{\text {hitung }}$ adalah 10,00 sedangkan nilai $t_{\text {tabel }}$ adalah 1,98 . Nilai $t_{\text {hitung }}(10,00)>t_{\text {tabel }}(1,98)$ sehingga $\mathrm{H}_{0}$ ditolak. Berdasarkan penelitian tersebut, dapat disimpulkan bahwa terdapat pengaruh yang signifikan kecerdasan numerik $\left(\mathrm{X}_{1}\right)$ terhadap kemampuan matematis $(\mathrm{Y})$. Kecerdasan numerik yang dimiliki siswa akan memudahkan siswa untuk meningkatkan kemampuan intelektual dalam berpikir matematis. Sehingga terdapat pengaruh positif yang signifikan antara kec erdasan numerik terhadap kemampuan matematis.

\section{Pengaruh Kecerdasan Spasial Terhadap Kemampuan Matematis}

Berdasarkan data dan analisis yang dilakukan diperoleh hasil korelasi antara variabel kecerdasan spasial $\left(\mathrm{X}_{2}\right)$ terhadap kemampuan matematis $(\mathrm{Y})$ yaitu sebesar 0,42 ; sehingga kecerdasan spasial memberikan pengaruh yang cukup signifikan terhadap kemampuan matematis sebesar 17,35\%. Artinya kontribusi variabel $\mathrm{X}_{2}$ terhadap $\mathrm{Y}$ sebesar $17,35 \%$ sedangkan sisanya $82,65 \%$ dipengaruhi oleh faktor lain.

Persamaan regresi pada penelitian ini adalah $\hat{Y}=2,47+0,95 X$, Berarti bahwa setiap peningkatan 1 data kecerdasan visual-spasial akan memberikan kenaikan sebesar 0,95 terhadap kemampuan matematis siswa. Setelah melakukan uji linieritas kecerdasan spasial $\left(\mathrm{X}_{2}\right)$ terhadap kemampuan matematis $(\mathrm{Y})$ didapat $\mathrm{F}_{\text {hitung }}<\mathrm{F}_{\text {tabel }}$ yaitu 1,24 $<2,18$ berarti data berpola linier, sehingga analisis regresi dapat dilanjutkan.

Kemudian dilakukan uji lanjut koefisien regresi sederhana memakai uji t dengan membandingkan antara nilai $t_{\text {hitung }}$ dengan nilai $t_{\text {tabel }}$, diperoleh nilai $t_{\text {hitung }}$ adalah 14,80 sedangkan nilai $t_{\text {tabel }}$ adalah 1,98 . Nilai $\mathrm{t}_{\text {hitung }}(14,80)>\mathrm{t}_{\text {tabel }}(1,98)$ sehingga $\mathrm{H}_{0}$ ditolak.

Berdasarkan penelitian tersebut dapat disimpulkan bahwa terdapat pengaruh yang signifikan kecerdasan spasial $\left(\mathrm{X}_{2}\right)$ terhadap kemampuan matematis $(\mathrm{Y})$. 
Kecerdasan spasial yang dimiliki siswa akan memudahkan siswa untuk meningkatkan kemampuan siswa dalam memvisualisasikan gambar suatu objek atau pola, serta dapat menafsirkan bentuk-bentuk tiga dimensi yang mencakup titik, garis, sudut, sisi, bidang ataupun ruang. Sehingga terdapat pengaruh positif yang signifikan antara kecerdasan spasial terhadap kemampuan matematis.

\section{PENUTUP}

1. Terdapat pengaruh yang signifikan Kecerdasan Numerik $\left(\mathrm{X}_{1}\right)$ dan Kecerdasan Spasial $\left(\mathrm{X}_{2}\right)$ secara bersama-sama terhadap Kemampuan Matematis Siswa (Y).

2. Terdapat pengaruh yang signifikan Kecerdasan Numerik $\left(X_{1}\right)$ terhadap Kemampuan Matematis Siswa (Y).

3. Terdapat pengaruh yang signifikan Kecerdasan Spasial $\left(\mathrm{X}_{2}\right)$ terhadap Kemampuan Matematis Siswa (Y).

\section{DAFTAR PUSTAKA}

Achdiyat Maman, dkk. 2014. Dasar Pendidikan Sebagai Pengantar. Tangerang : Pustaka Mandiri. Angkowo, R dan A. Kosasih. 2007. Optimalisasi Media Pembelajaran. Jakarta: Grasindo. Campbell, Bruce, Linda Campbell dan Dee Dickinson. 2005. Metode Praktis Pembelajaran Berbasis Multiple Intelligences. Depok: Intuisi Press.

Irawan, Ari. 2014. Pengaruh Kecerdasan Numerik dan Penguasaan Konsep Matematika Terhadap Kemampuan Berpikie Kritik Matematika. Jurnal AdMathEdu:Vol.4 No.1, hlm. 46-55.

Irawan, Ari. 2016. Peranan Kemampuan Numerik dan Verba dalam Berpikir Kritis Matematika pada Tingkat Sekolah Menengah Atas. Jurnal AdMathEdu:Vol.6 No.2, (Desember 2016)

Jayantika, T. (2013). Kontribusi Bakat Numerik, Kecerdasan Spasial, Dan Kecerdasan Logis Matematis Terhadap Prestasi Belajar Matematika Siswa Sd Negeri Di Kabupaten Buleleng, 2(1).

Northern Illinois University, Faculty Development and Instructional Design Center facdev@niu.edu,www.niu.edu/facdev, 815.753.0595.

Pease, Barbara dan Allan. 2009. Why Men Can Only Do One Thing at One Time and Women Can't Stop Talking. Jakarta: PT. Cahaya Insani Suci.

Rahmah, N. (2013). Hakikat Pendidikan Matematika. 2, 1-10.

Sugiyono. 2017.Metode Penelitian Kuantitatif, Kualitatif, dan R\&D. Bandung: Alfabeta. Tim

Penyusun Kamus Pusat Bahasa, Kamus Bahasa Indonesia, h. 729.

Trisna Jayantika, "Kontribusi Bakat Numerik, Kecerdasan Spasial, dan Kecerdasan Logis Matematis terhadap Prestasi Belajar Matematika Siswa", e-Journal Program Pascasarjana Universitas Pendidikan Ganesha Program Studi Matematika, Vol. 2, (2013).

Undang-undang Republik Indonesia Nomor 2 tentang Sistem Pendidikan Nasional. 1990.

Jakarta: PT. Armas Duta Jaya.

W.J.S. Purwadarminta. 2006.Kamus Umum,. Jakarta: Balai Pustaka,1086.

Zaenal,M. Abidin. 2010. Teori Belajar Guilford. http://meetabied.wordpress.com. 20 Maret 2010. 